\title{
Cezary Zapała
}

Uniwersytet Marii Curie-Skłodowskiej w Lublinie

cezary.zapala@gmail.com

\section{Prawne aspekty obrotu żywnością genetycznie modyfikowaną w Unii Europejskiej i Polsce}

\author{
Legal Aspects of Trading Genetically Modified Food \\ in the European Union and Poland
}

\section{STRESZCZENIE}

Tematem artykułu jest zagadnienie obrotu żywnością genetycznie modyfikowaną w Unii Europejskiej i Polsce. Autor, wychodząc od genezy regulacji GMO w UE i Polsce, przybliża problematykę, analizując przepisy materialne i proceduralne. Rozważanie ma na celu ustalenie, w jaki sposób obowiązujące przepisy wpływają na działalność przedsiębiorców z sektora biotechnologii oraz czy w pełni realizują regułę przezorności obecną w przepisach Traktatu o funkcjonowaniu Unii Europejskiej (będącego jedną z podstawowych obowiązujących zasad dotyczących zachowania odpowiednich ram bezpieczeństwa zdrowia ludzi i zwierząt). Autor przybliża również problematykę klauzuli opt-out w odniesieniu do przepisów GMO. opt-out

Słowa kluczowe: genetycznie modyfikowane organizmy; GMO; prawo żywnościowe; klauzula

\section{WSTĘP}

Żywność genetycznie modyfikowana jest tematem dyskusji publicznej, w której uczestniczą przedsiębiorcy, naukowcy oraz osoby niezwiązane bezpośrednio z uprawami czy obrotem produktów genetycznie modyfikowanych (GM). Swoje stanowisko formują także konsumenci żywności reprezentowani przez zrzeszenia i stowarzyszenia.

Z prawnego punktu widzenia jednym z najbardziej problematycznych zagadnień związanych z wykorzystaniem organizmów genetycznie modyfikowanych (GMO) jest sformułowanie legalnych i bezpiecznych ram produkcji oraz obrotu 
produktami genetycznie modyfikowanymi. Obrót żywnością genetycznie zmodyfikowaną zasługuje na uwagę również ze względu na trwające negocjacje między Unią Europejską a Stanami Zjednoczonymi dotyczące podpisania TTIP (Transatlantic Trade and Investment Partnership), której celem jest zawarcie porozumienia odnośnie do strefy wolnego handlu ${ }^{1}$. Biorąc pod uwagę różnice w prawie żywnościowym obowiązującym w Stanach Zjednoczonych i Unii Europejskiej co do wprowadzania do obrotu GMO, obawy państw członkowskich związane z obecnością na rynku nieoznaczonych produktów genetycznie modyfikowanych są uzasadnione.

Celem niniejszego opracowania jest analiza i ocena prawnych regulacji wprowadzenia produktów GM do obrotu z uwzględnieniem procedury obowiązującej w Unii Europejskiej oraz prawie polskim.

\section{PROBLEMATYKA GMO W PRZEPISACH OBOWIĄZUJĄCYCH W UNII EUROPEJSKIEJ}

\section{Geneza regulacji GMO w Unii Europejskiej}

Unia Europejska jako organizacja międzynarodowa, zrzeszająca państwa o różnej historii, rozwoju gospodarczym, wrażliwości społecznej i podejściu do zagadnień związanych z szeroko pojętą wolnością, już na samym początku musiała zmierzyć się z problemem odrębności w poglądach państw wchodzących w jej skład dotyczących GMO.

Na początku lat 90 . XX w. zostały przygotowane pierwsze akty prawne regulujące wykorzystanie efektów biotechnologii - nauki, która zapoczątkowała rozwój modyfikacji genetycznej roślin i zwierząt ${ }^{2}$. Negocjacje co do ustanowienia legalnych norm GMO rozpoczęły się dekadę wcześniej³. W czerwcu 1999 r. między innymi Dania, Luksemburg, Francja, Włochy i Grecja oświadczyły, iż

\footnotetext{
www.mg.gov.pl/Wspolpraca+miedzynarodowa/Handel+zagraniczny/TTIP [dostęp:25.01.2016].

2 Pierwszym aktem prawnym regulującym to zagadnienie była dyrektywa $\mathrm{nr}$ 90/220/EEC z dnia 23 kwietnia 1990 r. o zamierzonym uwolnieniu do środowiska organizmów genetycznie zmodyfikowanych. Szerzej na ten temat zob. D. Vogel, Ships Passing in the Night: The Changing Politics of Risk Regulation in Europe and the United States, www.researchgate.net/publication/4772432_Ships_Passing in the Night The Changing_Politics_of_Risk_Regulation_in_Europe and the United_States [dostęp: 10.03.2016]; L.A. Patterson, Regulating Biotechnology in the European Union: Institutional Responses to Internal Conflict Within the Commission, Pittsburgh 1997.

3 Już w 1983 r. Komisja w komunikacie do Rady, zatytułowanym Biotechnology in the Community, stwierdziła, że konieczne jest przygotowanie odpowiednich badań i regulacji w tym zakresie. Zob. European Commission, Biotechnology in the Community, Communication from the Commission to the Council COM (83) 672 final/2: E8-E9 z dnia 29 września 1983 r.
} 
„W nawiązaniu do zasady przezorności ulega zawieszeniu wszelka działalność zmierzająca do autoryzacji nowych produktów genetycznie zmodyfikowanych na rynku krajowym"4. Również inne państwa, takie jak Finlandia, Niemcy, Hiszpania i Holandia, wezwały Komisję Europejską do rozpoczęcia prac nad ustaleniem ram prawnych związanych z identyfikacją $\mathrm{GMO}^{5}$, mającą stworzyć jednolity system prawa obowiązujący w całej Wspólnocie.

Ta sytuacja spowodowała, iż Unia Europejska skonstruowała szczegółowe ramy prawne związane z obrotem żywnością genetycznie modyfikowaną, a w szczególności z jej znakowaniem, identyfikacją, oznaczaniem, nadzorem i kontrolą oraz informowaniem społeczeństwa o ewentualnych zagrożeniach i toczących się postępowaniach. Bardzo silny nacisk ze strony państw członkowskich przyczynił się też do wprowadzenia zasady przezorności, a czasowo obowiązująca zasada równorzędności została zastąpiona nowymi regulacjami. W niecały rok po oświadczeniu, złożonym między innymi przez Danię, Luksemburg, Francję, Włochy i Grecję w Nairobi, w trakcie V posiedzenia Stron Konwencji o różnorodności biologicznej, Unia Europejska podpisała Konwencję o różnorodności biologicznej ${ }^{6}$, a 25 czerwca 2002 r. - zgodnie z decyzją Rady Europy - w imieniu Unii Europejskiej został podpisany Protokół z Kartageny ${ }^{7}$. Konwencja o różnorodności biologicznej wśród zasad wskazywała regułę przezorności ${ }^{8}$, która została uznana przez Unię Europejską jako priorytetowa, w wyniku czego została ona ujęta w TWE9 i stała się podstawą przy przygotowywaniu kolejnych aktów prawnych. Zasada ta oznacza, iż w przypadku braku zagrożenia trwałymi i niemożliwymi do usunięcia zmianami, brak pełnej naukowej pewności co do potencjalnych zagrożeń nie może

4 M. Szkarłat, Żywność genetycznie zmodyfikowana w stosunkach międzynarodowych, Lublin 2011, s. 299.

5 Na 2194. posiedzeniu Rady, które odbyło się w dniach 24-25 czerwca 1994 r., zostały złożone dwie odrębne, ale podobne deklaracje. Pierwsza z nich została przedłożona przez grupę państw, w skład której weszły Dania, Grecja, Francja, Włochy i Luksemburg. Członkami drugiej grupy były delegacje z Austrii, Belgii, Finlandii, Niemiec, Holandii, Hiszpanii i Szwecji. Do żadnej z grup nie przyłączyła się Irlandia, Portugalia i Wielka Brytania. Szerzej o tym zagadnieniu zob. M. Lee, EU Regulation of GMOs: Law and Decision Making for a New Technology, Edward Elgar Publishing, 2008, s. 3.

6 Konwencja została przyjęta w maju 1992 r. w Nairobi i została otwarta do podpisu podczas „Szczytu Ziemi” w Rio de Janeiro. Konwencja weszła w życie 29 grudnia 1993 r.

7 Decyzja Rady z dnia 25 czerwca 2002 r. dotycząca zawarcia w imieniu Wspólnoty Protokołu z Kartageny (Dz.Urz. WE z 2002 r., L 628).

8 Zasada przezorności jest 15. zasadą znajdującą się w Konwencji o różnorodności biologicznej.

9 Aktualnie zasada przezorności znajduje się w art. 191 ust. 2 Traktatu o funkcjonowaniu Unii Europejskiej, tj. w części trzeciej Polityka i działanie wewnętrzne Unii, w rozdziale XX Środowisko naturalne. Przepis ten formułuje również zasadę prewencji, zasadę ,zanieczyszczający płaci”, zasadę wysokiego poziomu ochrony oraz zasadę usuwania szkód u źródła. Są to podstawowe zasady wspólnotowego prawa ochrony środowiska. 
być przeszkodą do zaniechania kosztownych działań, aby zapobiec ewentualnej degradacji środowiska.

Problematyka GMO została kompleksowo ujęta w dyrektywie Parlamentu Europejskiego i Rady 2001/18/WE z dnia 12 marca 2001 r. w sprawie zamierzonego uwalniania do środowiska organizmów zmodyfikowanych genetycznie i uchylającej dyrektywę Rady 90/220/EWG ${ }^{10}$. Akt ten został przyjęty na skutek dynamicznego rozwoju biotechnologii oraz dyskusji dotyczącej szeroko pojętego bezpieczeństwa żywności ${ }^{11}$. Najistotniejszym celem prac nad dyrektywą było utworzenie prawa, które pozwoliłoby zapewnić wysoki poziom ochrony zdrowia ludzkiego bez wprowadzania restrykcyjnego systemu wydawania zezwolen ${ }^{12}$. Jednocześnie podany akt prawny opiera się na naukowej ocenie ryzyka ${ }^{13}$, której założeniem jest, iż przed uwolnieniem organizmu genetycznie modyfikowanego do środowiska konieczna jest ocena zagrożenia, jakie może ewentualnie grozić w przypadku dopuszczenia go do obrotu. W przypadku wystąpienia sytuacji, w której państwo uwolniło do środowiska GMO, które stało się źródłem zanieczyszczenia środowiska lub spowodowało wystąpienie szkód w zdrowiu ludzi lub zwierząt, jest ono zobligowane do rekompensaty i naprawienia krzywdy zgodnie z zasadą ,zanieczyszczający płaci”14. Przepisy zobowiązują wnioskodawcę również do monitorowania produktów GMO wprowadzonych do obrotu w celu kontrolowania, nadzorowania i identyfikowania zagrożeń ${ }^{15}$.

Wraz z przyjęciem przez Parlament Europejski i Radę Europejską rozporządzenia $\mathrm{nr}$ 1946/2003 w sprawie transgranicznego przemieszczania organizmów genetycznie zmodyfikowanych ${ }^{16}$ została zapewniona odpowiednia prawna ochrona ram transportowania, przekazywania oraz wykorzystywania żywności genetycznie

${ }^{10}$ Dyrektywa Parlamentu Europejskiego i Rady 2001/18/WE z dnia 12 marca 2001 r. w sprawie zamierzonego uwalniania do środowiska organizmów zmodyfikowanych genetycznie i uchylająca dyrektywę Rady 90/220/EWG (Dz.Urz. L 106, 17 kwietnia 2001, P. 0001-0039).

${ }_{11}$ I. Wrześniewska-Wal, Żywność genetycznie zmodyfikowana. Aspekty prawne, Warszawa 2008, s. 38.

${ }^{12}$ D. Franzone, Polityka Wspólnoty Europejskiej dotyczaca organizmów modyfikowanych genetycznie, referat wygłoszony na konferencji Instytutu na Rzecz Ekorozwoju pt. „GMO poznajmy swoje poglądy", Warszawa 11-12 kwietnia $2003 \mathrm{r}$.

13 Załącznik II pkt b do Dyrektywy 2001/18/WE stanowi: ,Zgodnie z zasadą ostrożności podczas przeprowadzania oceny ryzyka dla środowiska naturalnego należy stosować następujące zasady ogólne $[\ldots] "$.

${ }^{14}$ Zasada ta znajduje się w Traktacie o funkcjonowaniu Unii Europejskiej. Uwzględnia ją również Dyrektywa Parlamentu Europejskiego i Rady 2004/35/WE z dnia 21 kwietnia 2004 r. w sprawie odpowiedzialności za środowisko w odniesieniu do zapobiegania i zaradzania szkodom wyrządzonym środowisku naturalnemu (Dz.Urz. L 143, 30 kwietnia 2004, P. 0056-0075).

${ }_{15}$ Pkt 43 Preambuły Dyrektywy 2001/18/WE; załącznik VII do Dyrektywy 2001/18/WE.

16 Rozporządzenie PE i Rady (WE) nr 1946/2003 z dnia 15 lipca 2003 r. w sprawie transgranicznego przemieszczania organizmów genetycznie zmodyfikowanych (Dz.Urz. WE z 2003 r., L 287). 
zmodyfikowanej (czyli obrotu). Rozporządzenie wprowadziło przepisy wskazane w Protokole z Kartageny, które stały się podstawą do utworzenia odpowiednich regulacji mających zapewnić odpowiedni poziom bezpieczeństwa związanego z transportowaniem, przekazywaniem i wykorzystywaniem żywności genetycznie zmodyfikowanej. Szczególny nacisk na ochronę jest widoczny w Preambule do rozporządzenia, w której uwzględniono zrównoważone wykorzystywanie różnorodności biologicznej oraz wskazano konieczność zastosowania odpowiedniego oznakowania, kontrolowania, nadzorowania i oceniania ryzyka związanego z transgranicznym przemieszczaniem się organizmów genetycznie zmodyfikowanych ${ }^{17}$.

\section{Klauzula opt-out}

Zgodnie z art. 2 ust. 2 Traktatu o funkcjonowaniu Unii Europejskiej, w którym przewidziano możliwość dzielenia kompetencji między UE a państwami członkowskimi, została wprowadzona dyrektywa nr 2015/412 z dnia 11 marca 2015 r. w sprawie zmiany dyrektywy 2001/18 w zakresie umożliwienia państwom członkowskim ograniczenia lub zakazu uprawy organizmów zmodyfikowanych genetycznie (GMO) na swoim terytorium ${ }^{18}$. Wskazany akty prawny ustanowił klauzulę opt-out. Umożliwia ona, aby państwo, po wprowadzeniu określonej uprawy GMO przez Unię Europejską do obrotu, mogło zadecydować, czy chce ograniczyć lub zakazać określonej uprawy bez wskazania przyczyn naukowych. Klauzula wprowadza większą swobodę i elastyczność w decydowaniu przez kraj członkowski o tworzeniu gospodarki opartej na uprawach żywności genetycznie modyfikowanej bądź na tworzeniu upraw w całości lub części wolnych od modyfikacji genetycznej.

Wprowadzenie klauzuli opt-out jest rozwiązaniem kompromisowym, choć zwolennicy GMO wskazują, iż jej zastosowanie powoduje znaczące ograniczenie upowszechniania upraw genetycznie modyfikowanych roślin ${ }^{19}$. Argument ten znajduje potwierdzenie w statystykach. Wraz z wejściem w życie dyrektywy nr 2015/412 aż 19 państw członkowskich, w tym Polska ${ }^{20}$, zadeklarowało skorzystanie z klauzuli opt-out co do aktualnie dopuszczonych przez Unię Europejską upraw roślin GM, w tym aż 16 państw poinformowało o wprowadzeniu całkowitego zakazu, zaś trzy państwa - o ograniczeniu upraw genetycznie modyfikowanych wyłącznie do określonych terenów ${ }^{21}$.

${ }_{17}$ Pkt 4 i 16 Preambuły do rozporządzenia nr 1946/2003.

${ }_{18}$ Pkt 6 Preambuły oraz art. 26c dyrektywy 2001/18/WE.

19 http://gmo.blog.polityka.pl/2016/01/05/przelomowy-rok [dostęp: 25.01.2016].

${ }^{20}$ Pisma Ministra Środowiska z dnia 22 września 2015 r. do Komisji Europejskiej (m.in. o sygn. DLP-VI-43-4/35712/15).

${ }_{21}$ Two thirds of EU states reject GMO crops, file cultivation opt-out requests, www.rt.com/ news/317638-eu-gmo-cultivation-opt-out [dostęp: 25.01.2016]. Państwa objęte klauzulą: Belgia (tylko Walonia), Bułgaria, Dania, Niemcy (poza celami badawczymi), Grecja, Francja, Chorwa- 
Wprowadzenie klauzuli opt-out wiązało się z licznymi kontrowersjami. Zarówno ministrowie rolnictwa państw członkowskich, jak i Parlament Europejski dążyli do jej odrzucenia, wskazując, iż wprowadzenie jej jest sprzeczne z zasadami jednolitego rynku oraz postanowieniami Światowej Organizacji Handlu² ${ }^{22}$ Zakaz upraw GMO jest istotnym ograniczeniem dla przedsiębiorstw biotechnologicznych, dla których przeprowadzanie badań nad organizmami genetycznie modyfikowanymi może być niekorzystne ekonomicznie, w następstwie czego rozwój technologii w tym zakresie będzie mniej dynamiczny.

Mimo wskazanych zastrzeżeń w listopadzie 2015 r. Komisja Europejska uznała, iż 19 państw członkowskich, które zadeklarowały ograniczenie lub zakaz upraw genetycznie modyfikowanych, będzie wykluczonych z dystrybucji nasion $\mathrm{GMO}^{23}$. 3 marca 2016 r. w Dzienniku Urzędowym Unii Europejskiej została opublikowana decyzja wykonawcza Komisji UE 2016/321, która zakazuje upraw genetycznie zmodyfikowanej kukurydzy MON $810^{24}$ na terenach państw wnioskujących ${ }^{25}$.

Klauzula opt-out może okazać się barierą przy negocjacjach dotyczących TTIP. W Stanach Zjednoczonych uprawy GM stanowią około 85-90\% (w Unii Europejskiej jest to około $0,5 \%)^{26}$. Nie da się zatem wykluczyć, iż stworzenie strefy wolnego handlu spowoduje nagły przypływ genetycznie modyfikowanej żywności do państw członkowskich. Stanowisko Stanów Zjednoczonych w tym zakresie jest dość jednoznaczne i ogranicza się do uznania, iż amerykańskie rolnictwo nie może być w żaden sposób wykluczone. Mimo że produkty rolno-spożywcze nie są najważniejszym punktem negocjacji TTIP, to wskazuje się, że mogą przyczynić się nawet do jej zawieszenia ${ }^{27}$. Unia Europejska utrzymuje, iż obowiązujące przepisy dotyczące GMO nie są przedmiotem negocjacji TTIP i nie zostaną zmienione ${ }^{28}$.

cja, Włochy, Cypr, Łotwa, Litwa, Luksemburg, Węgry, Malta, Holandia, Austria, Polska, Słowenia, Wielka Brytania (poza Irlandią Północną, Szkocją i Walią).

${ }^{22}$ Projekt KE ws. zakazu stosowania GMO bez szans na przyjęcie, www.polskieradio. pl/42/273/Artykul/1476176,Projekt-KE-ws-zakazu-stosowania-GMO-bez-szans-na-przyjecie [dostęp: 25.01.2016].

${ }^{23}$ Ile państw bez GMO?, www.farmer.pl/produkcja-roslinna/nasiennictwo/ile-panstw-bez-gmo,60997.html [dostęp: 25.01.2016].

${ }^{24}$ Kukurydza MON 810 to w chwili wprowadzenia decyzji wykonawczej Komisji 2016/321 jedyny organizm genetycznie modyfikowany dopuszczony do obrotu na terenie UE.

${ }_{25}$ Decyzja wykonawcza Komisji (UE) 2016/321 z dnia 3 marca 2016 r. dostosowująca zakres geograficzny zezwolenia na uprawę zmodyfikowanej genetycznie kukurydzy (Zea mays L.) MON 810 (Dz.Urz. z 2016 r., L 60/90).

${ }^{26}$ W USA nie chca znakować żywności GMO. To skomplikuje umowę o wolnym handlu między UE a USA?, www.polskieradio.pl/42/273/Artykul/1410991,W-USA-nie-chca-znakowac-zywnosci-GMO-To-skomplikuje-umowa-o-wolnym-handlu-miedzy-UE-a-USA [dostęp: 10.05.2016].

${ }^{27}$ Umowa UE-USA może otworzyć drzwi dla GMO, http://csr.forbes.pl/umowa-ue-usa-moze-otworzyc-drzwi-dla-amerykanskiej-zywnosci-gmo,artykuly,183807,1,1.html [dostęp: 10.05.2016].

${ }^{28} \mathrm{http} / / /$ ec.europa.eu/trade/policy/in-focus/ttip/about-ttip/questions-and-answers/index pl.htm [dostęp: 10.05.2016]. 


\section{Wprowadzenie GMO do obrotu w UE}

Przepisy Unii Europejskiej możemy uznać za restrykcyjne i szczegółowe, a ich celem jest zapewnienie najwyższego poziomu ochrony zdrowia zarówno ludzi, jak i zwierząt, przy jednoczesnym znaczącym ograniczeniu swobody działalności przedsiębiorców zainteresowanych wprowadzaniem do obrotu na terenie państw członkowskich UE produktów GM.

Przygotowanie odpowiednich przepisów proceduralnych regulujących obrót żywnością genetycznie modyfikowaną w Unii Europejskiej było konieczne do pełnego ujednolicenia regulacji prawnych państw członkowskich w zakresie obrotu produktami genetycznie modyfikowanymi ${ }^{29}$. Podstawowymi aktami prawnymi, w których określono ramy prawne dotyczące obrotu GMO, są dyrektywa nr 2001/18/WE oraz rozporządzenie $\mathrm{nr}$ 1946/2003/WE ${ }^{30}$, uzupełniającymi zaś są rozporządzenie $\mathrm{nr}$ 1829/2003/WE ${ }^{31}$ i rozporządzenie $\mathrm{nr}$ 1830/2003/WE ${ }^{32}$.

Istotnym elementem wprowadzenia żywności genetycznie modyfikowanej do obrotu w Unii Europejskiej jest poddanie jej urzędowej kontroli, która realizuje zasadę przezorności.

\section{Europejska urzędowa kontrola żywności}

Pierwszym aktem prawnym szczegółowo regulującym problematykę urzędowej kontroli żywności było rozporządzenie nr 178/200233, w którym określono wymogi dotyczące urzędowej kontroli żywności. Wprowadzono w nim przepisy nakładające na państwa członkowskie obowiązek prawnego uregulowania kwestii związanych z monitorowaniem i kontrolą przestrzegania przepisów z zakresu prawa żywnościowego przez podmioty działające na rynku spożywczym, a także z udzielaniem opinii publicznej informacji dotyczących bezpieczeństwa i ryzyka związanego z żywnością i paszami ${ }^{34}$.

${ }^{29}$ Art. 1 dyrektywy nr 2001/18.

${ }_{30}$ Rozporządzenie PE i Rady (WE) nr 1946/2003 z dnia 15 lipca 2003 r. w sprawie transgranicznego przemieszczania organizmów genetycznie zmodyfikowanych (Dz.Urz. L 287, 5 listopada 2003, P. 0001-0010).

31 Rozporządzenie PE i Rady (WE) nr 1829/2003 z dnia 22 września 2003 r. w sprawie genetycznie zmodyfikowanej żywności i paszy (Dz.Urz. L 268, 18 października 2003, P. 0001-0023).

32 Rozporządzenie PE i Rady (WE) nr 1830/2003 z dnia 22 września 2003 r. dotyczące możliwości śledzenia i etykietowania organizmów zmodyfikowanych genetycznie oraz możliwości śledzenia żywności i produktów paszowych wyprodukowanych z organizmów zmodyfikowanych genetycznie i zmieniające dyrektywę 2001/18/WE (Dz.Urz. L 268, 18 października 2003, P. 0024-0028).

33 Rozporządzenie PE i Rady (WE) nr 178/2002 z dnia 28 stycznia 2002 r. ustanawiające ogólne zasady i wymagania prawa żywnościowego, powołujące Europejski Urząd ds. Bezpieczeństwa Żywności oraz ustanawiające procedury w zakresie bezpieczeństwa żywności (Dz.Urz. L 031, 1 lutego 2002, P. 0001-0024).

${ }^{34}$ Art. 17 ust. 2 rozporządzenia nr 178/2002. 
Przepisy znajdujące się w rozporządzeniu nr 178/2002 okazały się zbyt ogólne i konieczne stało się przygotowanie bardziej szczegółowych norm, które znalazły się w rozporządzeniu nr 854/2004 ustanawiającym szczególne przepisy dotyczące organizacji urzędowych kontroli w odniesieniu do produktów pochodzenia zwierzęcego przeznaczonych do spożycia przez ludzi ${ }^{35}$, a także w rozporządzeniu $\mathrm{nr}$ $882 / 2004$ w sprawie urzędowych kontroli przeprowadzanych w celu sprawdzenia zgodności z prawem paszowym i żywnościowym oraz regułami dotyczącymi zdrowia zwierząt i dobrostanu zwierząt ${ }^{36}$.

Rozporządzenie nr 882/2004 precyzuje zakres urzędowej kontroli i definiuje ją jako każdą bezstronną oraz skuteczną formę kontroli, jaka jest wykonywana w celu sprawdzenia zgodności z prawem paszowym i żywnościowym oraz regułami dotyczącymi zdrowia zwierząt i dobrostanu zwierząt. Każda kontrola powinna odbywać się zgodnie z wystandaryzowanymi procedurami reprezentującymi wysoką jakość kontroli ${ }^{37}$.

Dodatkowo Komisja Europejska kontroluje sposób realizacji przepisów dotyczących urzędowej kontroli żywności, wykorzystując do tego Dyrekcję Generalną ds. Zdrowia i Bezpieczeństwa Żywności (DG SANTE) i ustanowione przez nią Biuro ds. Weterynarii Żywności (FVO), które po wejściu w życie rozporządzeń nr 1829/2003 i 1830/2003 ocenia również sposób przeprowadzania kontroli w odniesieniu do transportu, przetwarzania i wprowadzania do sprzedaży produktów GMO.

\section{Tryb postępowania w sprawie wprowadzenia GMO do obrotu na terenie $\mathbf{U E}$}

Postępowanie związane z wprowadzeniem GMO do obrotu składa się z trzech etapów. Pierwszy wiąże się ze złożeniem wniosku o zezwolenie wprowadzenia do obrotu produktu genetycznie zmodyfikowanego; drugi - z dokonaniem oceny wniosku oraz uwzględnieniem zagadnienia bezpieczeństwa i zasadności wprowadzenia GMO do obrotu, które jest realizowane przez Europejski Urząd Bezpieczeństwa Żywności; trzeci - z wydaniem zezwolenia.

35 Rozporządzenie PE i Rady (WE) nr 854/2004 z dnia 29 kwietnia 2004 r. ustanawiające szczególne przepisy dotyczące organizacji urzędowych kontroli w odniesieniu do produktów pochodzenia zwierzęcego przeznaczonych do spożycia przez ludzi (Dz.Urz. L 139, 30 kwietnia 2004, P. 0206-0319).

36 Rozporządzenie PE i Rady (WE) nr 882/2004 z dnia 29 kwietnia 2004 r. w sprawie kontroli urzędowych przeprowadzanych w celu sprawdzenia zgodności z prawem paszowym i żywnościowym oraz regułami dotyczącymi zdrowia zwierząt i dobrostanu zwierząt (Dz.Urz. L 165, 30 kwietnia 2004, P. 0001-0141).

37 Szerzej na ten temat w części: „Krajowa urzędowa kontrola żywności”. 
Producent, chcąc uzyskać zezwolenie na wprowadzenie GMO do obrotu, musi swój zamiar poprzedzić złożeniem wniosku, który będzie odpowiadał następującemu zakresowi wykorzystania:

- wykorzystanie produktu GMO tylko jako żywność,

- wykorzystanie produktu GMO jako żywność i nie tylko,

- wykorzystanie produktu GMO jako żywności i paszy ${ }^{38}$.

Wybrany wniosek musi być prawidłowo wypełniony. Przed przedłożeniem zgłoszenia do odpowiedniego organu krajowego $0^{39}$ przedsiębiorca musi przygotować uzupełniony dokument wraz z wypełnionym obszernym formularzem ${ }^{40}$. W przypadku, gdy do produkcji produktu GMO użyto innego produktu GMO lub produktu zawierającego GMO, wnioskodawca ma obowiązek załączyć dodatkowe informacje, które są wskazane w art. 5 ust. 5 rozporządzenia nr 1829/2003 ${ }^{41}$.

Następnie wniosek należy przedłożyć krajowemu organowi kompetentnemu do jego przyjęcia, w którym produkt GM ma trafić do obrotu w pierwszej kolejności. Organ ten ma 14 dni na pisemne potwierdzenie otrzymania kompletnego wnio$\mathrm{sku}^{42}$. Przesyła on abstrakt z zawartości złożonych akt do Europejskiego Urzędu ds. Bezpieczeństwa Żywności (EFSA). W kolejnym kroku EFSA informuje Komisję Europejską i państwa członkowskie o złożeniu takiego wniosku i przedstawia wniosek wraz z ewentualnymi dodatkowymi informacjami złożonymi przez producenta. Ten etap postępowania jest określany jako krajowy.

Po przeprowadzeniu badan i analiz przez EFSA powstaje raport wskazujący ocenę ryzyka wprowadzenia do obrotu danego produktu genetycznie modyfikowanego wraz z adnotacją opiniującą, czy dany produkt można wprowadzić, a jeżeli tak, to na jakich warunkach. Raport przedkładany jest Komisji, a po sprawdzeniu, czy nie zawiera informacji poufnych, publikowany jest przez EFSA ${ }^{43}$.

${ }^{38}$ I. Wrześniewska-Wal, op. cit., s. 113.

39 W Polsce tym organem jest Główny Inspektorat Sanitarny.

${ }^{40}$ Art. 5 rozporządzenia nr 1829/2003 zawiera dane, jakie należy podać we wniosku o wydanie zezwolenia.

${ }^{41}$ Art. 5 ust. 5 rozporządzenia nr 1829/2003 brzmi: „W przypadku GMO lub żywności zawierającej lub składającej się z GMO do wniosku należy załączyć również: a) pełne dossier techniczne zawierające informacje wymagane na podstawie załącznika III i IV do Dyrektywy 2001/18/WE oraz informacje i wnioski dotyczące oceny ryzyka przeprowadzonej zgodnie z zasadami ustalonymi w załączniku II do Dyrektywy 2001/18/WE lub, w przypadku wprowadzania do obrotu GMO zatwierdzonego na podstawie części C Dyrektywy 2001/18/WE, kopię decyzji w sprawie wydania zezwolenia; b) plan monitorowania skutków dla środowiska naturalnego zgodny z załącznikiem VII do Dyrektywy 2001/18/WE, w tym propozycję okresu obowiązywania planu monitorowania; okres obowiązywania może odbiegać od sugerowanego terminu osiągnięcia porozumienia”.

42 Art. 5 ust. 2 lit. a) rozporządzenia nr 1829/2003 brzmi: „Właściwy organ krajowy w terminie 14 dni od daty otrzymania wniosku na piśmie poświadcza wnioskodawcy jego otrzymanie. Poświadczenie wskazuje datę otrzymania wniosku".

${ }^{43}$ I. Wrześniewska-Wal, op. cit., s. 134. 


\section{Europejski Urząd Bezpieczeństwa Żywności}

Europejski Urząd Bezpieczeństwa Żywności (EFSA) jest niezależnym organem doradczym dokonującym oceny ryzyka wprowadzanego do obrotu genetycznie modyfikowanego produktu zgodnie z rozporządzeniem $\mathrm{nr}$ 178/200244. Wydana przez niego ocena stanowi podstawę do wydania przez Komisję decyzji o zezwoleniu na wprowadzenie żywności GMO do obrotu na terenie UE.

Zadaniem EFSA jest zapewnienie wysokiego poziomu ochrony środowiska, zdrowia ludzi i dobrostanu zwierząt. Urząd posiada obszerne instrukcje dotyczące procedury wydawania opinii, które zostały określone w rozporządzeniu nr $1304 / 2003^{45}$. EFSA musi mieć pewność co do zasadności swojej opinii, ponieważ pomyłki w przygotowywaniu oceny ryzyka mogą doprowadzić do ograniczenia zaufania i podważania w przyszłości kolejnych ocen. EFSA należy do organów autonomicznych. Członkowie urzędu nie są reprezentantami władz czy przedsiębiorstw $^{46}$, w następstwie czego przygotowywane przez EFSA opracowania naukowe, opinie i oceny są niezależne i oparte na badaniach naukowych ${ }^{47}$.

Urząd, po otrzymaniu wniosku od krajowego organu przyjmującego zgłoszenie, jest zobowiązany do poinformowania Komisji Europejskiej i państw członkowskich o złożeniu takiego wniosku (niezwłocznie po stwierdzeniu przez niego braków formalnych). Następnie EFSA udostępnia informacje o złożeniu wniosku opinii publicznej i w ciągu 6 miesięcy wydaje naukową opinię odnośnie do złożonego zgłoszenia. Wskazany termin jest instrukcyjny i może być przedłużony za każdym razem, kiedy urząd zgłosi wnioskodawcy konieczność przedłożenia dodatkowych danych ${ }^{48}$. Opinia z uwzględnieniem oceny ryzyka wraz z uzasadnieniem trafia do Komisji i państw członkowskich oraz wnioskodawcy. Urząd publikuje opinię po usunięciu wszelkich informacji uznanych w świetle przepisów art. 30 rozporządzenia nr 1829/2003 za poufne. Od dnia publikacji opinia publiczna ma 30 dni na zgłoszenie swoich uwag, sprzeciwów lub zastrzeżeńt ${ }^{49}$.

Procedura wprowadzenia GMO do obrotu jest szczegółowa, rozbudowana i długotrwała. Wiąże się z przeprowadzeniem badań, wypełnieniem szczegółowego

${ }^{44}$ Art. 23 rozporządzenia nr 178/2002.

${ }^{45}$ Komisja Europejska, Dyrekcja Generalna ds. Komunikacji Społecznej, Zrozumieć polityke Unii Europejskiej - Bezpieczeństwo żywności, Urząd Publikacji Unii Europejskiej, 2014; rozporządzenie Komisji (WE) nr 1304/2003 z dnia 11 lipca 2003 r. w sprawie procedury stosowanej przez Europejski Urząd ds. Bezpieczeństwa Żywności do kierowanych do niego wniosków o wydanie opinii naukowej (Dz.Urz. L 185, 24 lipca 2003, P. 0006-0008).

${ }^{46} \mathrm{http} / /$ europa.eu/about-eu/agencies/regulatory_agencies_bodies/policy_agencies/efsa/index_pl.htm [dostęp: 30.03.2016].

${ }^{47}$ I. Wrześniewska-Wal, op. cit., s. 127.

48 Art. 6 ust. 1 i 2 rozporządzenia nr 1829/2003.

49 Art. 6 ust. 7 rozporządzenia nr 1829/2003. 
formularza, oczekiwaniem na ocenę ryzyka, konieczną opinię innych podmiotów oraz ewentualne uwagi, które niezależnie od etapu postępowania mogą skutkować odmową wydania zezwolenia. Tak skonstruowane postępowanie realizuje obowiązującą obecnie zasadę przezorności i zabezpiecza interesy konsumentów.

\section{Zezwolenie na wprowadzenie do obrotu produktu GMO}

Decyzja o zezwoleniu na wprowadzenie produktu genetycznie modyfikowanego do obrotu, wydana przez Komisję Europejską, jest ostatnim etapem postępowania związanego z uwalnianiem GMO i ma charakter powszechnie obowiązujący w państwach członkowskich przez okres określony w decyzji.

Komisja od chwili uzyskania opinii od EFSA ma 3 miesiące na złożenie projektu decyzji o zezwoleniu do Stałego Komitetu Łańcucha Żywnościowego i Zdrowia Zwierząt ${ }^{50}$, który jest oparty na opinii EFSA, ale może wyrażać zdanie odrębne. Ostatnim punktem przed wydaniem ostatecznej decyzji o wprowadzeniu produktu genetycznie modyfikowanego do obrotu jest głosowanie. Jeżeli projekt zostanie zaaprobowany, Komisja bezzwłocznie informuje wnioskodawcę i publikuje szczegóły decyzji w Dzienniku Urzędowym UE ${ }^{51}$.

Wydane zezwolenie obowiązuje we wszystkich państwach członkowskich. W konsekwencji przedsiębiorca nie musi informować wszystkich państw oddzielnie o uzyskanym zezwoleniu. Okres ważności zezwolenia wynosi 10 lat (termin rozpoczyna się w chwili wydania decyzji). Zatwierdzony produkt GM wpisuje się do publicznego rejestru będącego bazą danych prowadzoną przez Komisję ${ }^{52}$. Wpis kończy postępowanie. Wraz z nim wnioskodawca otrzymuje uprawnienie do legalnego obrotu produktem GM na terenie UE.

Wydane zezwolenie jest wzruszalne i w każdej chwili może zostać zmienione, zawieszone, a nawet cofnięte. Może to nastąpić w sytuacjach nadzwyczajnych po wszczęciu odpowiedniej procedury przez EFSA (z własnej inicjatywy urzędu), na wniosek państwa członkowskiego lub Komisji, jeżeli powzięto informacje, iż wprowadzony produkt GM jest szkodliwy dla zdrowia ludzi, zwierząt lub środowiska. Po przekazaniu przez EFSA opinii do Komisji, państw członkowskich i wnioskodawcy, mają one 30 dni na wniesienie uwag, z którymi zapoznaje się Komisja Europejska wydająca decyzje co do zmiany, zawieszenia lub cofnięcia zezwolenia ${ }^{53}$.

Po upływie 10 lat możliwe jest odnowienie zezwolenia ${ }^{54}$. Przedsiębiorca jest zobligowany najpóźniej rok przed upływem ważności zezwolenia do złożenia no-

\footnotetext{
${ }^{50}$ Art. 7 ust. 1 rozporządzenia nr 1829/2003.

${ }^{51}$ Art. 5 decyzji Rady 1999/468.

${ }^{52}$ Art. 7 ust. 5 rozporządzenia nr 1829/2003.

53 Art. 53 i 54 rozporządzenia nr 178/2002.

${ }^{54}$ Art. 44 rozporządzenia nr 1829/2003.
} 
wego wniosku uzupełnionego o kopię dotychczasowego zezwolenia oraz sprawozdanie z wyników monitoringu (jeżeli jest to wskazane w zezwoleniu) i dodatkowe informacje, zmiany lub uzupełnienia, które pojawiły się w trakcie obowiązywania poprzedniego zezwolenia.

\section{PROBLEMATYKA GMO W PRZEPISACH OBOWIĄZUJĄCYCH W POLSCE}

\section{Przepisy materialne}

Pierwszym kompleksowym aktem prawnym normującym zagadnienie organizmów genetycznie zmodyfikowanych była ustawa z dnia 22 czerwca $2001 \mathrm{r}$. o mikroorganizmach i organizmach genetycznie zmodyfikowanych, która weszła w życie 26 października $2001 \mathrm{r}^{55}$ Reguluje ona podstawowe kwestie związane z GMO, a w szczególności przewóz i tranzyt GMO, uwalnianie GMO do środowiska w celu obrotu, zamknięte użycie GMO, a także właściwości organów administracyjnych w sprawach dotyczących GMO. Przedmiotowy akt prawny został zmieniony ustawą z dnia 15 stycznia 2015 r. o zmianie ustawy o organizmach genetycznie zmodyfikowanych oraz niektórych innych ustaw, która weszła w życie 30 marca 2015 r. $^{56}$

Aktami wykonawczymi do powołanej ustawy są: rozporządzenie Ministra Środowiska z dnia 27 października 2015 r. w sprawie wzoru wniosku o wydanie zezwolenia na wprowadzenie do obrotu produktu $\mathrm{GMO}^{57}$ oraz rozporządzenie Ministra Środowiska z dnia 27 października 2015 r. w sprawie wzoru wniosku o wydanie zezwolenia na zamierzone uwolnienie organizmu genetycznie zmodyfikowanego do środowiska ${ }^{58}$. Rozporządzenia regulują zagadnienie wprowadzania do obrotu organizmów genetycznie zmodyfikowanych, określając wzory wniosków, jakie należy stosować w celu uzyskania zgody na zamknięte użycie organizmów genetycznie zmodyfikowanych oraz zamierzone uwolnienie GMO do środowiska w celach innych niż wprowadzenie do obrotu, a także uzyskania zezwolenia na wprowadzenie do obrotu produktów GMO.

${ }^{55}$ Ustawa z dnia 22 czerwca 2001 r. o mikroorganizmach i organizmach genetycznie zmodyfikowanych (Dz.U. z 2001 r., nr 76, poz. 811 z późn. zm.).

${ }^{56}$ Ustawa z dnia 15 stycznia 2015 r. o zmianie ustawy o organizmach genetycznie zmodyfikowanych oraz niektórych innych ustaw (Dz.U. z 2015 r., poz. 277).

57 Rozporządzenie Ministra Środowiska z dnia 27 października 2015 r. w sprawie wzoru wniosku o wydanie zezwolenia na wprowadzenie do obrotu produktu GMO (Dz.U. z 2015 r., poz. 1820).

${ }^{58}$ Rozporządzenie Ministra Środowiska z dnia 27 października 2015 r. w sprawie wzoru wniosku o wydanie zezwolenia na zamierzone uwolnienie organizmu genetycznie zmodyfikowanego do środowiska (Dz.U. z 2015 r., poz. 1817). 
Wskazane regulacje prawne dotyczą w szczególności wdrożenia przepisów prawa międzynarodowego dotyczących organizmów genetycznie modyfikowanych, których stroną jest Polska, oraz transpozycji przepisów unijnych do krajowego porządku. Polska jako strona klauzuli opt-out nie zezwala na uprawę nasion GM, choć nie ingeruje w ich obrót.

\section{Wprowadzenie GMO do obrotu w Polsce}

Na mocy ustawy o nasiennictwie ${ }^{59}$ na terenie naszego kraju możliwy jest obrót nasionami GMO. Powołana ustawa w Tytule X Przepisy zmieniające, przejściowe $i$ końcowe wprowadziła zmiany w ustawie z dnia 18 grudnia 2003 r. o ochronie roślin $^{60}$, zgodnie z którymi kontrola przestrzegania zasad i obowiązujących wymagań w zakresie wytwarzania, oceny, przechowywania, obrotu i stosowania materiału siewnego objęła nasiona genetycznie modyfikowane. Ponadto zgodnie z ustawą o mikroorganizmach i organizmach genetycznie zmodyfikowanych możliwe jest wykorzystywanie GMO w celach laboratoryjnych ${ }^{61}$. Natomiast na podstawie ustawy o paszach ${ }^{62}$ dopuszczony został obrót genetycznie modyfikowanych pasz (w przypadku tego ostatniego przygotowywane jest rozporządzenie mające je zakazać od 2017 r. $)^{63}$.

Jednakże, mimo dopuszczonego obrotu GMO w Polsce, w 2013 r. zabroniono upraw kukurydzy MON 810 ${ }^{64}$, wydając rozporządzenie oparte na art. 104 ust. 9 ustawy z dnia 9 listopada 2012 r. o nasiennictwie. Dodatkowo Polska zadeklarowała we wrześniu 2015 r. zastosowanie klauzuli opt-out ${ }^{65}$.

\section{Krajowa urzędowa kontrola żywności}

W Polsce produkty GMO podlegają kontroli i nadzorowi licznych organów i inspekcji, których uprawnienia się pokrywają. Brak kompleksowego rozdzielenia kompetencji stwarza spory między urzędami. Sytuacja ta prowadzi do sytuacji

${ }_{59}$ Art. 127 ust. 2 lit. b pkt 3 ustawy z dnia 9 listopada 2012 r. o nasiennictwie (Dz.U. z 2012 r., poz. $1512 \mathrm{z}$ dnia 28 grudnia 2012 r.).

${ }^{60}$ Ustawa z dnia 18 grudnia 2003 r. o ochronie roślin (Dz.U. z 2008 r., nr 133, poz. 849 $\mathrm{z}$ późn. $\mathrm{zm}$.).

${ }^{61}$ Art. 1 ustawy z dnia 22 czerwca 2001 r. o mikroorganizmach i organizmach genetycznie zmodyfikowanych (Dz.U. z 2015 r., poz. 806).

${ }_{62}$ Ustawa z dnia 22 lipca 2006 r. o paszach (Dz.U. z 2014 r., poz. 398 z dnia 27 marca 2014 r.).

${ }^{63} \mathrm{http}: / / g m o . b l o g . p o l i t y k a . p 1 / 2015 / 10 / 31 /$ gmo-box-office-pazdziernik-4 [dostęp: 28.01.2016].

${ }^{64}$ Rozporządzenie Rady Ministrów z dnia 2 stycznia 2013 r. w sprawie zakazu stosowania materiału siewnego odmian kukurydzy MON 810 (Dz.U. z 2014 r., poz. 1085).

${ }^{65} \mathrm{http} / / /$ ec.europa.eu/food/plant/docs/gmo_auth_cult_pl_bt11xmir604xga21.pdf [dostęp: 28.01.2016]; Polska chce być wolna od GMO, www.pb.p1/4311191,55173,polska-chce-byc-wolna-od-gmo [dostęp: 28.01.2016]. 
patowych, w których producenci muszą przedstawiać identyczne dokumenty i sporządzać kilkakrotnie opinie na ten sam temat dla różnych organów ${ }^{66}$.

W ramach krajowych systemów kontroli żywności mamy do czynienia z kontrolą wewnętrzną (zależną od producenta) oraz kontrolą urzędową (niezależną od producenta). Kontrola wewnętrzna opiera się na zasadach Dobrej Praktyki Produkcyjnej (GMP), Dobrej Praktyki Rolnej (GAP), Dobrej Praktyki Laboratoryjnej (GLP), systemie zapewnienia jakości (TQM), Analizie Zagrożeń i Krytycznych Punktów Kontroli (HACCP) oraz systemach zarządzania jakością zgodnie z normami ISO $9000^{67}$, które mają charakter obligatoryjny i wyznaczają standardy w produkcji i nadzorze.

Kontrola urzędowa GMO została usankcjonowana w przepisach ustawy o mikroorganizmach i organizmach genetycznie modyfikowanych ${ }^{68}$, na mocy których organami kompetentnymi do nadzoru jest minister właściwy do spraw środowiska wraz z inspekcjami: Państwową Inspekcją Sanitarną ${ }^{69}$, Inspekcją Weterynaryjną ${ }^{70}$, Inspekcją Ochrony Roślin i Nasiennictwa ${ }^{71}$, Inspekcją Ochrony Środowiska ${ }^{72}$, Inspekcją Handlową ${ }^{73}$, Państwową Inspekcją Pracy ${ }^{74}$, Inspekcją Jakości Handlowej Artykułów Rolno-Spożywczych ${ }^{75}$ oraz Organami Administracji Celnej ${ }^{76}$.

\section{PODSUMOWANIE}

Wprowadzenie produktu genetycznie modyfikowanego na terenie Unii Europejskiej jest ściśle powiązane z koniecznością przeprowadzenia wnikliwej i długiej procedury, która pozwala na szczegółowe zbadanie produktu i określenie ryzyka

${ }^{66}$ www.food-law.pl [dostęp: 17.05.2015].

${ }^{67}$ I. Wrześniewska-Wal, op. cit., s. 186.

${ }^{68}$ Art. 10 ustawy o mikroorganizmach i organizmach genetycznie zmodyfikowanych. Kompetencje inspekcji wynikają z innych ustaw i rozporządzeń.

${ }_{69}$ Art. 4 ust. 2 pkt 4 ustawy z dnia 14 marca 1985 r. o Państwowej Inspekcji Sanitarnej (Dz.U. z 2015 r., poz. 1412).

${ }^{70}$ Art. 3 ust. 2 pkt 5 lit. c ustawy z dnia 29 stycznia 2004 r. o Inspekcji Weterynaryjnej (Dz.U. z 2015 r., poz. 1482).

${ }^{71}$ Art. 81 pkt 3 ustawy z dnia 18 grudnia 2003 r. o ochronie roślin (Dz.U. z 2016 r., nr 17).

72 Art. 2 ust. 1 pkt 1 lit. h ustawy z dnia 20 lipca 1991 r. o Inspekcji Ochrony Środowiska (Dz.U. z 2013 r., nr 686).

${ }^{73}$ Art. 3 ust. 1 pkt 2e i 2 f ustawy z dnia 15 grudnia 2000 r. o Inspekcji Handlowej (Dz.U. z 2014 r., nr 148).

${ }^{74}$ Art. 10 ust. 1 pkt 9 ustawy z dnia 13 kwietnia 2007 r. o Państwowej Inspekcji Pracy (Dz.U. z 2015 r., nr 640).

75 Art. 17 ustawy z dnia 21 grudnia 2000 r. o jakości handlowej artykułów rolno-spożywczych (Dz.U. z 2015 r., nr 678).

${ }^{76}$ Art. 54 ustawy z dnia 22 czerwca 2001 r. o mikroorganizmach i organizmach genetycznie zmodyfikowanych (Dz.U. 2001, nr 76, poz. 811 z późn. zm.). 
związanego z jego obrotem i uprawą. Wskazane regulacje, choć powstały w wyniku kompromisu wypracowanego przez państwa członkowskie UE, są uznawane przez przedsiębiorców za zbyt duże ingerowanie w obrót gospodarczy. Niektóre koncerny decydują się na przerwanie procedury wprowadzania GMO do obrotu w Unii Europejskiej z powodu przedłużającego się postępowania i braku uzasadnienia ekonomicznego co do uwolnienia GMO na rynku europejskim ${ }^{77}$. Szczegółowa procedura wprowadzania produktów genetycznie modyfikowanych do obrotu powoduje, że tylko producenci dysponujący znacznymi środkami pieniężnymi są w stanie zrealizować jej założenia.

Obowiązujące regulacje prawne realizują zasadę przezorności, która wyższy priorytet przyznaje ochronie zdrowia ludzi i zwierząt niż nieskrępowanemu obrotowi gospodarczemu, ukierunkowanemu na osiągnięcie zysku. Obowiązujące przepisy regulują procedurę, która mimo swojej szczegółowości jest możliwa do zrealizowania przez wnioskodawcę i może zakończyć się dodaniem go do rejestru, jeżeli produkt GM spełnia wszystkie wymogi i jest uznany za bezpieczny w chwili jego wpisu. Popularność klauzuli opt-out i liczne deklaracje państw członkowskich co do jej zastosowania wskazuje również, iż społeczność nie jest przekonana do zasadności uwalniania GMO, zwłaszcza że konsumenci darzą zaufaniem produkty naturalne, nieprzetworzone, a modyfikacje genetyczne wiążą się z licznymi obawami ${ }^{78}$. $Z$ tej przyczyny szczegółowa procedura wpływa bezpośrednio na zapewnienie odpowiedniego poziomu bezpieczeństwa, a w następstwie na akceptację GMO wśród społeczności.

Obowiązujące przepisy należy uznać za akceptowalne zarówno dla przedsiębiorców, jak i konsumentów. Pozwalają one czuć się bezpiecznie społeczeństwu, które może przez władzę ustawodawczą ograniczyć obrót i uprawy GMO na terenie swojego kraju. Zarazem nie zakazują one możliwości rejestracji produktów GM. Aktualne przepisy mogłyby zostać zliberalizowane o unormowania wspierające przedsiębiorstwa zajmujące się przeprowadzaniem badań z zakresu GMO, a w szczególności o koncerny zarejestrowane na terenie Unii Europejskiej, które mogłyby tworzyć konkurencyjne rozwiązania w stosunku do spółek ze Stanów Zjednoczonych Ameryki Północnej.

77 Syngenta withdraws two EU applications for GMO products, www.reuters.com/article/syngenta-gmo-idUSL8N12D4AD20151013 [dostęp: 10.05.2016].

${ }^{78}$ E. Priwieziencew, Co spoleczeństwo myśli o GMO, opinie konsumentów i pozarządowych organizacji ekologicznych, I Ogólnopolska Konferencja inaugurująca kampanię informacyjną pt. „Genetycznie zmodyfikowane organizmy, a środowisko przyrodnicze", Warszawa 25 kwietnia 2008 r. 


\section{BIBLIOGRAFIA}

Decyzja Rady z dnia 25 czerwca 2002 r. dotycząca zawarcia w imieniu Wspólnoty Protokołu z Kartageny (Dz.Urz. WE z 2002 r., L 628).

Decyzja wykonawcza Komisji (UE) 2016/321 z dnia 3 marca 2016 r. dostosowująca zakres geograficzny zezwolenia na uprawę zmodyfikowanej genetycznie kukurydzy (Zea mays L.) MON 810 (Dz.Urz. z 2016 r., L 60/90).

Dyrektywa nr 90/220/EEC z dnia 23 kwietnia 1990 r. o zamierzonym uwolnieniu do środowiska organizmów genetycznie zmodyfikowanych .

Dyrektywa Parlamentu Europejskiego i Rady 2001/18/WE z dnia 12 marca 2001 r. w sprawie zamierzonego uwalniania do środowiska organizmów zmodyfikowanych genetycznie i uchylająca dyrektywę Rady 90/220/EWG (Dz.Urz. L 106, 17 kwietnia 2001, P. 0001-0039).

Dyrektywa Parlamentu Europejskiego i Rady 2004/35/WE z dnia 21 kwietnia 2004 r. w sprawie odpowiedzialności za środowisko w odniesieniu do zapobiegania i zaradzania szkodom wyrządzonym środowisku naturalnemu (Dz.Urz. L 143, 30 kwietnia 2004, P. 0056-0075).

European Commission, Biotechnology in the Community, Communication from the Commission to the Council COM (83) 672 final/2: E8-E9 z dnia 29 września 1983 r.

Franzone D., Polityka Wspólnoty Europejskiej dotyczaca organizmów modyfikowanych genetycznie, referat wygłoszony na konferencji Instytutu na Rzecz Ekorozwoju pt. „GMO poznajmy swoje poglądy", Warszawa 11-12 kwietnia $2003 \mathrm{r}$.

http://ec.europa.eu/food/plant/docs/gmo_auth_cult_pl_bt11xmir604xga21.pdf_[dostęp: 28.01.2016]. http://ec.europa.eu/trade/policy/in-focus/ttip/about-ttip/questions-and-answers/index_pl.htm [dostęp: 10.05.2016].

http://europa.eu/about-eu/agencies/regulatory_agencies_bodies/policy_agencies/efsa/index_pl.htm [dostęp: 30.03.2016].

http://gmo.blog.polityka.pl/2015/10/31/gmo-box-office-pazdziernik-4 [dostęp: 28.01.2016].

http://gmo.blog.polityka.p1/2016/01/05/przelomowy-rok [dostęp: 25.01.2016].

Ile państw bez GMO?, www.farmer.pl/produkcja-roslinna/nasiennictwo/ile-panstw-bez-gmo,60997. html [dostęp: 25.01.2016].

Komisja Europejska, Dyrekcja Generalna ds. Komunikacji Społecznej, Zrozumieć politykę Unii Europejskiej - Bezpieczeństwo żywności, Urząd Publikacji Unii Europejskiej, 2014.

Lee M., EU Regulation of GMOs: Law and Decision Making for a New Technology, Edward Elgar Publishing, 2008.

Patterson L.A., Regulating Biotechnology in the European Union: Institutional Responses to Internal Conflict Within the Commission, Pittsburgh 1997.

Pisma Ministra Środowiska z dnia 22 września 2015 r. do Komisji Europejskiej (m.in. o sygn. DLP-VI-43-4/35712/15).

Polska chce być wolna od GMO, www.pb.pl/4311191,55173,polska-chce-byc-wolna-od-gmo [dostęp: 28.01.2016].

Priwieziencew E., Co społeczeństwo myśli o GMO, opinie konsumentów i pozarządowych organizacji ekologicznych, I Ogólnopolska Konferencja inaugurująca kampanię informacyjną pt. „Genetycznie zmodyfikowane organizmy a środowisko przyrodnicze", Warszawa 25 kwietnia $2008 \mathrm{r}$.

Projekt KE ws. zakazu stosowania GMO bez szans na przyjęcie, www.polskieradio.p1/42/273/ Artykul/1476176,Projekt-KE-ws-zakazu-stosowania-GMO-bez-szans-na-przyjecie [dostęp: 25.01.2016].

Rozporządzenie Komisji (WE) nr 1304/2003 z dnia 11 lipca 2003 r. w sprawie procedury stosowanej przez Europejski Urząd ds. Bezpieczeństwa Żywności do kierowanych do niego wniosków o wydanie opinii naukowej (Dz.Urz. L 185, 24 lipca 2003, P. 0006-0008). 
Rozporządzenie PE i Rady (WE) nr 178/2002 z dnia 28 stycznia 2002 r. ustanawiające ogólne zasady i wymagania prawa żywnościowego, powołujące Europejski Urząd ds. Bezpieczeństwa Żywności oraz ustanawiające procedury w zakresie bezpieczeństwa żywności (Dz.Urz. L 031, 1 lutego 2002, P. 0001-0024).

Rozporządzenie PE i Rady (WE) nr 1829/2003 z dnia 22 września 2003 r. w sprawie genetycznie zmodyfikowanej żywności i paszy (Dz.Urz. L 268, 18 października 2003, P. 0001-0023).

Rozporządzenie PE i Rady (WE) nr 1830/2003 z dnia 22 września 2003 r. dotyczące możliwości śledzenia i etykietowania organizmów zmodyfikowanych genetycznie oraz możliwości śledzenia żywności i produktów paszowych wyprodukowanych z organizmów zmodyfikowanych genetycznie i zmieniające dyrektywę 2001/18/WE (Dz.Urz. L 268, 18 października 2003, P. 0024-0028).

Rozporządzenie PE i Rady (WE) nr 1946/2003 z dnia 15 lipca 2003 r. w sprawie transgranicznego przemieszczania organizmów genetycznie zmodyfikowanych (Dz.Urz. WE z 2003 r., L 287).

Rozporządzenie PE i Rady (WE) nr 854/2004 z dnia 29 kwietnia 2004 r. ustanawiające szczególne przepisy dotyczące organizacji urzędowych kontroli w odniesieniu do produktów pochodzenia zwierzęcego przeznaczonych do spożycia przez ludzi (Dz.Urz. L 139, 30 kwietnia 2004, P. 0206-0319).

Rozporządzenie PE i Rady (WE) nr 882/2004 z dnia 29 kwietnia 2004 r. w sprawie kontroli urzędowych przeprowadzanych w celu sprawdzenia zgodności z prawem paszowym i żywnościowym oraz regułami dotyczącymi zdrowia zwierząt i dobrostanu zwierząt (Dz.Urz. L 165, 30 kwietnia 2004, P. 0001-0141).

Rozporządzenie Ministra Środowiska z dnia 27 października 2015 r. w sprawie wzoru wniosku o wydanie zezwolenia na wprowadzenie do obrotu produktu GMO (Dz.U. z 2015 r., poz. 1820).

Rozporządzenie Ministra Środowiska z dnia 27 października 2015 r. w sprawie wzoru wniosku o wydanie zezwolenia na zamierzone uwolnienie organizmu genetycznie zmodyfikowanego do środowiska (Dz.U. z 2015 r., poz. 1817).

Rozporządzenie Rady Ministrów z dnia 2 stycznia 2013 r. w sprawie zakazu stosowania materiału siewnego odmian kukurydzy MON 810 (Dz.U. z 2014 r., poz. 1085).

Syngenta withdraws two EU applications for GMO products, www.reuters.com/article/syngenta-gmo-idUSL8N12D4AD20151013 [dostęp: 10.05.2016].

Szkarłat M., Żywność genetycznie zmodyfikowana w stosunkach międzynarodowych, Lublin 2011.

Two thirds of EU states reject GMO crops, file cultivation opt-out requests, www.rt.com/news/317638eu-gmo-cultivation-opt-out [dostęp: 25.01.2016].

Umowa UE-USA może otworzyć drzwi dla GMO, http://csr.forbes.pl/umowa-ue-usa-moze-otworzyc-drzwi-dla-amerykanskiej-zywnosci-gmo,artykuly,183807,1,1.html [dostęp: 10.05.2016].

Ustawa z dnia 14 marca 1985 r. o Państwowej Inspekcji Sanitarnej (Dz.U. z 2015 r., poz. 1412).

Ustawa z dnia 20 lipca 1991 r. o Inspekcji Ochrony Środowiska (Dz.U. z 2013 r., nr 686).

Ustawa z dnia 15 grudnia 2000 r. o Inspekcji Handlowej (Dz.U. z 2014 r., nr 148).

Ustawa z dnia 21 grudnia 2000 r. o jakości handlowej artykułów rolno-spożywczych (Dz.U. z 2015 r., $\mathrm{nr} 678)$.

Ustawa z dnia 22 czerwca 2001 r. o mikroorganizmach i organizmach genetycznie zmodyfikowanych (Dz.U. z 2001 r., nr 76, poz. 811 z późn. zm.).

Ustawa z dnia 18 grudnia 2003 r. o ochronie roślin (Dz.U. z 2008 r., nr 133, poz. 849 z późn. zm.).

Ustawa z dnia 18 grudnia 2003 r. o ochronie roślin (Dz.U. z 2016 r., nr 17).

Ustawa z dnia 29 stycznia 2004 r. o Inspekcji Weterynaryjnej (Dz.U. z 2015 r., poz. 1482).

Ustawa z dnia 22 lipca 2006 r. o paszach (Dz.U. z 2014 r., poz. 398 z dnia 27 marca 2014 r.).

Ustawa z dnia 13 kwietnia 2007 r. o Państwowej Inspekcji Pracy (Dz.U. z 2015 r., nr 640).

Ustawa z dnia 9 listopada 2012 r. o nasiennictwie (Dz.U. z 2012 r., poz. 1512 z dnia 28 grudnia 2012 r.).

Ustawa z dnia 15 stycznia 2015 r. o zmianie ustawy o organizmach genetycznie zmodyfikowanych oraz niektórych innych ustaw (Dz.U. z 2015 r., poz. 277). 
Vogel D., Ships Passing in the Night: The Changing Politics of Risk Regulation in Europe and the United States, www.researchgate.net/publication/4772432_Ships_Passing_in_the_Night_The_Changing_Politics_of_Risk_Regulation_in_Europe_and_the_United_States [dostęp: 10.03.2016]. W USA nie chca znakować żywności GMO. To skomplikuje umowe o wolnym handlu między UE a USA?, www.polskieradio.pl/42/273/Artykul/1410991,W-USA-nie-chca-znakowac-zywnosci-GMO-To-skomplikuje-umowa-o-wolnym-handlu-miedzy-UE-a-USA [dostęp: 10.05.2016]. Wrześniewska-Wal I., Żywność genetycznie zmodyfikowana. Aspekty prawne, Warszawa 2008. www.food-law.pl [dostęp: 17.05.2015].

www.mg.gov.pl/Wspolpraca+miedzynarodowa/Handel+zagraniczny/TTIP [dostęp: 25.01.2016].

\section{SUMMARY}

The topic of this article concerns the notion of the release of genetically modified food in the European Union and Poland. The author of this work touches upon the problem concerning the origin of GMO regulations in UE and Poland based on the substantive and procedural rules. The aim of this consideration is to determine the way of how applicable provisions affect business activities regarding the branch of biotechnology and how these provisions comply with the rule of caution, being the part of the Treaty on the Functioning of the European Union (one of the basic and applicable rules concerning appropriate frames of health and animal safety). The author also concentrates on the problem of opt-out clause with reference to GMO provisions.

Keywords: genetically modified organism (GMO); food law; opt-out clause 